134 幕張テクノガー ゙ンのガーデン、アトリウムの照明試西

河角真人田中照雄坂睦夫

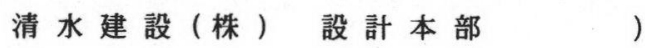
1.はじめに

幕張テクノガーデンは、幕張新都心に平成元年 4 月 にオープンした延 2016 、 $10000 \mathrm{~m}^{2}$ の大型複合インテ リジェントビルである。建物の名にもあるように「ガ ーテンを中心とした業務、研究罢境・技術と人間の調 和した最先端環境の実現」を基本コンセプトとしてお

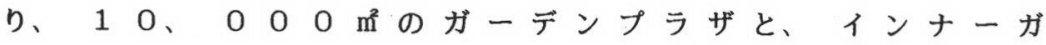
ーテンとして計画されたアトリウムにより、ここに矰 く人々に潤いと安らきを与えている。ここではその照 明計画を紹介する。

\section{2. ガーテンプラザの照明}

ここでは木と植栽に暖かみを持たせるため、白熱灯 で照らしあげる方式を中心としている。四季毎に表情 を変える落葉樹 42 2 本をグリッド状に配置し、異なる 光源を四季毎に変化させ、木々の美しさを引き出して いる。また中央の池は噴水と水中照明により水と光の 変化を演出し、中央に浮かぶステージにはフランスの 啀刻家マルタ・パンによる高さ $12 \mathrm{~m}$ のモニュメント を設置し、下ょりの投光照明によりこれを浮かび上が らせている。ガーテン内プロムナードにそって設置されたボラ一ドに足元灯を組み込み、 この通路の雾囲気作りを行つている。ガーテンを取り囲むショッピングモールは、暖色系 光源とシャーフな光源を時間で変化させ、モールの表情に変化を持たせている。 3.アトリウムの照明

建物の中央部には、フランスのヴィルモット事務所 の基本設計による「21 世紀のフランスの庭園」を表 現した 1、4 $000 \mathrm{~m}$ のアトリウムがある。白を基調と した空間に円錐形をした木と植裁が配置されている。 空間全体の照明としては、トラス屋根からの床面を照 らす照明と逆に下から屋根を照らしその反射によって 得られる光と植载灯にて明るさを得ている。またテ一 マ表現の一つとして壁面が光る面発光を用いている。 アトリウムをさらに奥に進むとピラミッド型立体トラ スの $24 \mathrm{~m}$ の吹抜け空間があり、大きな円錐形をした 4 本の木が空間にそびえている。 タルハライドランプと高压ナトリウムランプを合わせた混光スポットライトと植裁灯によ る照明とし、アトリウムから続く空間として統一されたイメージを表現している。 4.おわりに

竣工以来数力月を経ているが、ここで儌く多くの人々にくつろぎの空間として有効に利 用されている。本稿が高度情報化時代のオフィスビルのアメニティ空間の照明計画の一例 としてこ参考となれば幸いである。

Garden and a t ri um lighting of Makuhari technc garden,

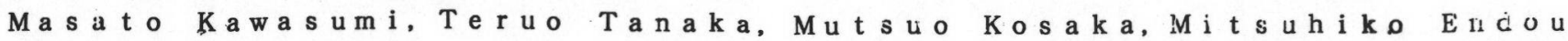

